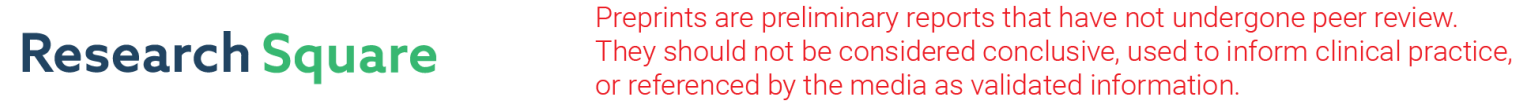 \\ The mechanisms of the impact of high-tech product export trade on regional carbon performance
}

\section{Miao Han ( $\nabla 1504552030 @ q q . c o m$ )}

Harbin Institute of Technology https://orcid.org/0000-0003-4151-609X

\section{Yan Zhou}

Harbin Institute of Technology

\section{Research Article}

Keywords: High-tech product export, Regional carbon performance, Industrial structure supererogation, Low-carbon technological innovation, Human capital accumulation, Mediation effect

Posted Date: March 31st, 2021

DOl: https://doi.org/10.21203/rs.3.rs-291543/v1

License: (c) (1) This work is licensed under a Creative Commons Attribution 4.0 International License. Read Full License 


\title{
The mechanisms of the impact of high-tech product export trade on regional carbon performance
}

\author{
Miao Han ${ }^{1}$. Yan Zhou ${ }^{1}$ \\ 1 School of Management, Harbin Institute of Technology, 13 Fayuan Street, Harbin, Nangang District 150001, \\ Harbin, China. \\ $\square$ Miao Han \\ elixir835@sina.com,1504552030@qq.com
}

\begin{abstract}
Export trade is a driving force of economic development, but it is also an important source of increasing carbon dioxide emissions. Against the background of suggestions of conflicts between economic development and environmental health, the proportion of high-tech products in the export trade of various countries has been rising, leading governments and scholars to focus on identifying the appropriate export structure for countries. While there is some knowledge on how high-tech product exports affect carbon dioxide emissions, the mechanisms involved in that link have not been adequately addressed in previous studies. This study is based on China's inter-provincial panel data from 2006 to 2017, and uses the fixed effects model stepwise regression method and the bootstrap method to systematically investigate the mediating effects of industrial structure supererogation, low-carbon technological innovation and human capital accumulation, operating in the impact of high-tech product export trade on regional carbon performance. The research results show that high-tech product exports can help improve regional carbon performance. The mediating variables, industrial structure supererogation, low-carbon technological innovation and human capital accumulation, separately have positive and partially mediating effects on the link between high-tech products export trade and regional
\end{abstract}


carbon performance. After considering the alternative indicator of regional carbon performance and the replacement of test method, the results of this study are still robust. The research results are instructive for an understanding of the relationship between high-tech product export trade and regional carbon performance. They highlight the important role of high-tech product exports in improving regional carbon performance, and have significance in promoting China's green and low-carbon transition.

Keywords High-tech product export, Regional carbon performance, Industrial structure supererogation, Low-carbon technological innovation, Human capital accumulation, Mediation effect

\section{Introduction}

China's Nationally Determined Contributions show that carbon dioxide emissions will peak around 2030, and China has committed to achieving that peak sooner. China's determination to control greenhouse gas emissions and to reduce its carbon dioxide emissions is further evident when by the general debate of the 75th United Nations General Assembly, President Xi Jinping indicated that the outbreak of the Covid-19 pandemic has inspired an acceleration of the green and low-carbon transition, increased the national independent contribution, inspired the adoption of more powerful policies and measures, and facilitated the ambition of reaching the peak of carbon dioxide emissions by 2030 .

According to WTO statistics, China reached a new milestone in the development of export trade and was ranked as the world's leader in export trade in 2013. This is a major achievement to China's adherence to trade opening and economic globalization. The leapfrog development of foreign trade has played an important part in promoting China's economy. However, export trade characterized by low added value and low 
technological content has intensified the growth of China's carbon dioxide emissions, causing China's carbon trade to account for more than $50 \%$ of the global carbon trade (Liddle, 2017). As a result, China has been recorded as the world's largest carbon dioxide emitter. Yan and Yang (2010) found that 10.03\%-26.54\% of China's annual carbon dioxide emissions are generated when exporting goods, and Liu et al. (2017) found that accumulated carbon dioxide emissions embodied in exports accounted for approximately $30 \%$ of the total emissions in China during 2002-2011. By using trade between China and the United States as an example, Xu et al. (2009) demonstrated that carbon dioxide emissions embodied in the exports from China to the USA represented approximately $8 \%-12 \%$ of China's carbon dioxide emissions.

Furthermore, the signing of the Kyoto Protocol also reflected the pressure on China's international trade competitive position that the rapid growth of greenhouse gas emissions has brought. For this reason, the export trade structure is in urgent need of transformation. The export of technology-intensive, energy-efficient products urgently needs to replace the export of high-energy, high-pollution, and low-tech products, thereby bringing greater opportunities for improving the country's international status and reducing carbon dioxide emissions.

There is no uniform definition for high-tech products. In China, there are basically two definitions of high-tech products in use. The first classifies all products of the high-tech industry as high-tech products. The second combines the characteristics of China's high-tech industry and solicits the opinions of management personnel from relevant ministries, commissions, bureaus, universities, research institutes and other units and relevant experts. The Ministry of Science and Technology promulgated that high-tech products be divided into nine categories, namely computer and communication technology, life science technology, electronic technology, computer integrated manufacturing technology, aerospace technology, optoelectronic technology, biotechnology, material technology and other technologies. This study chooses the second method to define high-tech products. To enhance 
China's position in the global value chain division of labor and trade competitiveness, promoting the export of high-tech products has become the main direction for upgrading the export structure. The export value of China's high-tech products and their proportion in total merchandise exports in the period 2006-2017 are shown in Figure 1.

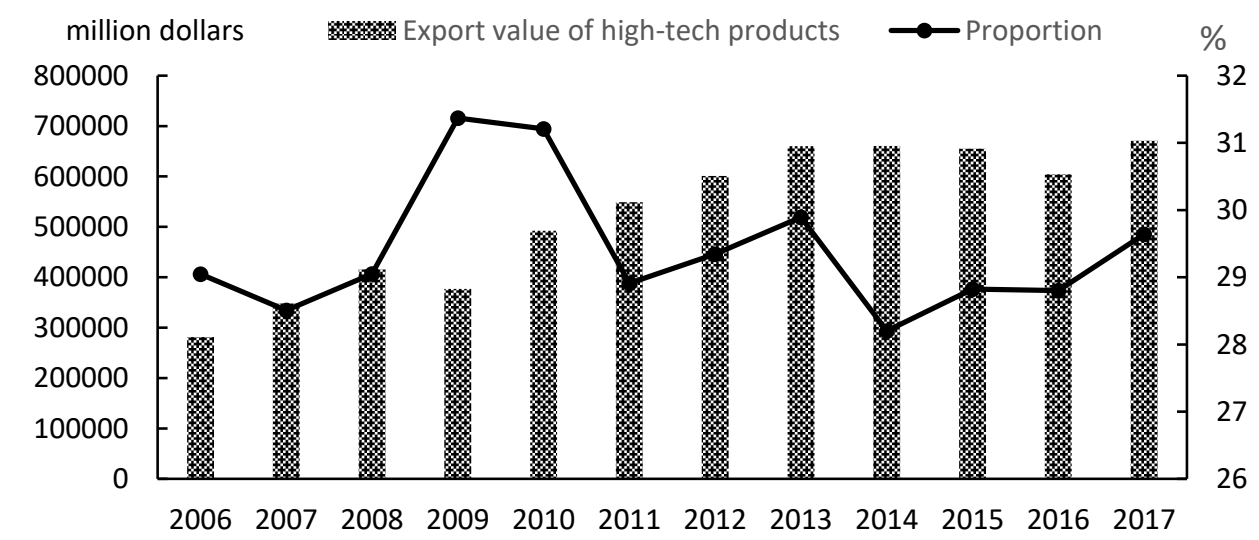

Fig. 1 The export value of China's high-tech products and their proportion in total merchandise exports (2006-2017). Source: The annual data of China Statistical Yearbook of Science and Technology and China Statistical Yearbook.

To reduce the increase in carbon dioxide emissions caused by export trade, the improvement of energy efficiency has always been considered an inevitable choice. Su and Thomson (2016) found that China contributed around 1,000 Mt of carbon dioxide emissions each year from 2006 to 2012 through its exports to numerous countries, while the energy efficiency improvements helped reduce emissions by about 2,469 Mt of carbon dioxide embodied emissions in exports. During the COVID-19 pandemic, the empirical research of Wang and Wang (2020) concluded that in order to prevent the retaliatory growth of carbon dioxide emissions, expanding trade and increasing energy consumption efficiency are still important driving factors for reducing carbon dioxide emissions. Meanwhile, energy efficiency improvements 
in certain industries are also the key to reducing greenhouse gas and air pollution emissions. For instance, China's cement industry is one of the largest energy-consuming, and greenhouse gas and air pollutant emitting industries, Zhang et al. (2015) showed that improving energy efficiency aids a reduction in the emission of carbon dioxide. Other sectors, including agriculture (Shabani et al., 2020), electricity (Babatunde et al., 2020), and transportation (Isik et al., 2021) combined with energy efficiency improvements will also contribute to carbon dioxide reductions.

While the extant literature provides useful insights, there has been the generation of limited knowledge on the impact of the expansion of high-tech product exports in a region on the total carbon performance of the region. Since China has officially entered the strategic track of achieving peak carbon dioxide emissions, China's provincial regions will have to consider the issue of achieving peak carbon dioxide emissions. For this reason, this study regards the provincial region as a unit to explore regional carbon dioxide emissions and considers the impact and mechanisms of high-tech product export trade on regional carbon performance. Although there exists literature on regional carbon performance (Wang and Zhao, 2020; Zhang et al., 2008; Su et al., 2020; Dong et al., 2020), there is still no uniform definition on regional carbon performance. To more accurately understand the regional carbon dioxide emissions and propose corresponding green and low-carbon development suggestions, it is significant to select appropriate regional carbon performance evaluation indicators. This study defines regional carbon performance as the reciprocal of carbon emission intensity. Carbon emission intensity is one of the widely-used indicators of carbon dioxide emissions in the world, and is expressed by the carbon dioxide emissions per unit of GDP in a given region. Therefore, the greater the carbon emission intensity, the lower will be the regional carbon performance; conversely, the lower the carbon emission intensity, the higher the regional carbon performance. As a major carbon emitter, China's competitiveness in the international market has been affected. One way of enhancing international competitiveness is to improve the 
position of the industry in the global value chain, that is, to promote the supererogation of the industrial structure (Tian et al., 2019). The supererogation of the industrial structure is an inevitable choice to solve the environmental energy pressure. It begs the question, however, whether the export of high-tech products affects carbon dioxide emissions through the supererogation of the industrial structure. Low-carbon technological innovation is a key factor in improving energy consumption efficiency and therefore, will the export trade of high-tech products promote the independent research and development of local technologies and the absorption of international technology spillovers to achieve low-carbon technological innovation? In the early stage of its economic development, China's high-tech products were mainly distributed in the eastern coastal areas. Human capital is relatively concentrated in these areas. Then, what is the relationship between the export of high-tech products and the accumulation of human capital? Does the development of high-tech product export trade affect carbon dioxide emissions through human capital?

The answers to these questions will aid the clarification of the impact mechanism of high-tech product export trade on regional carbon performance, and will fill the gaps in the extant literature. This study uses China's provincial regional panel data to explore the impact of high-tech product export trade on regional carbon performance, and to investigate whether high-tech product export trade can improve regional carbon performance through industrial structure upgrading, low-carbon technological innovation and human capital accumulation. In turn, it provides a certain basis and reference for the implementation of carbon dioxide emissions reduction targets, and will have important theoretical and practical significance for boosting the development of China's green economy. 


\section{Literature review and hypotheses}

\section{The direct relationship between the export trade of high-tech products and regional carbon performance}

Numerous scholars point out that export trade is an important source of carbon dioxide emissions from emerging economies (Yan and Yang, 2010; Liu et al., 2017; Shahzad et al., 2020; Wang et al., 2020; Shao,2020). Based on the comparative advantage theory driven by factor endowments, Cole (2006) indicated that trade increases the per capita energy consumption of exporting countries because the scale effect of export trade exceeds the technical effect. Kahrl and Roland-holst (2008) confirmed that exports are the largest source of China's energy demand growth. They proposed that addressing the economic and environmental challenges created by rapid energy demand growth will require a more comprehensive, supply chain perspective on energy-export linkages. Sadorsky (2011) analyzed the impact of trade growth on the energy demand in the Middle East and showed that a $1 \%$ increase in per capita exports increases per capita energy consumption by $0.11 \%$ while a $1 \%$ increase in per capita imports increases per capita energy consumption by $0.04 \%$. In addition, export trade will not only increase embodied carbon emissions, but also increase total carbon dioxide emissions. According to Weber et al. (2020), trade liberalization may increase global emissions. Those findings, therefore, highlight the importance of considering trade when designing carbon dioxide reduction strategies. Thus, some scholars analyzed the impact of export trade on carbon dioxide emissions from the perspective of increasing the technical content of export products. For instance, Khan et al. (2020) found that the theoretical basis for the increase in export trade to reduce consumption-based carbon emissions is that the increase in exports is related to the use of advanced technologies. Wang et al. (2020) demonstrated that technological progress in China's high-tech products field is conducive to reducing embodied carbon emissions from China's export trade to developed countries. Waheed et al. 
(2020) indicated that the Gulf Cooperation Council countries realized that rapid economic growth has an important relationship with a large number of international transactions and energy consumption, and found that turning to the export of high-tech products helps reduce total energy demand, energy intensity and carbon emissions. Based on these arguments and similar economic development models between China and the Gulf Cooperation Council countries, the following hypothesis is proposed:

Hypothesis 1. (H1): Expanding the export trade of high-tech products helps improve regional carbon performance.

\section{The mediating roles of industrial structure supererogation, low-carbon technological innovation, and human capital accumulation}

The supererogation of the industrial structure is based on the rationalization of the industry. It is a process of evolution towards a higher level of comprehensive productivity and technical structure, reflecting the general high-tech process of the industry. In the course of economic development, trade openness has expedited the process of structural upgrading (Jena and Barua, 2020). Na (2019) based his research on five countries in Africa, and found that expanding the export trade of technological products can help realize the growth of the technology sector and promote the upgrading of existing industries. To achieve sustainable economic development, scholars not only consider the driving role of industrial production technology in economic growth, but also incorporate resource and environmental factors into it, emphasizing the importance of industrial green technological. Wang and Xin (2020) used the viewpoint of ecological economics to analyze the positive impact of China's trade with participating countries of the "Belt and Road" initiative on the energy efficiency of China's logistics industry, and found that China's exports to these countries are of great significance to the realization of low-carbon industrial 
transformation and there is room for further release. This is consistent with the view that "Made in China 2025" emphasizes that industrial greening is an important entry point for industrial structure supererogation. Zhao et al. (2019) also showed that the excessive dependence on resource industries will inhibit the progress of the industrial structure, and efforts to transform resource-intensive industries into technology-intensive industries can support sustainable development. Scholars have linked trade with structure, technology and environment, but have rarely established a direct link between export trade of high-tech products and industrial structure supererogation. Therefore, the following hypothesis is proposed:

Hypothesis 2. (H2): Expanding the export trade of high-tech products is conducive to promoting supererogation of the industrial structure.

With the increasingly fierce global competition, export companies tend to choose to increase productivity through technological progress to obtain international competitiveness and corresponding profits. Perla et al. (2015) indicated that with the increase in export opportunities, the redistributive effect of open trade accelerates the opportunity for enterprises to adopt new technologies, and thus accelerates the speed at which exports promote technology diffusion. Some scholars also agree with the existence of learning-by-exporting. Esquivias and Harianto (2020), for example, argued that export activities contribute to promoting technological progress, because export companies need to compete in foreign markets. Mazzi et al. (2020) confirmed that the productivity of export companies has increased after entering the international market. Benkovskis et al. (2019) further stated that corresponding to export activities that generate high value-added in the global value chain, greater productivity increases. In addition, technological progress is not only used to increase productivity. Through reliance on the theory of comparative advantage, Song and Wang (2017) showed that technological progress is also an important technology to improve China's comparative advantage in international competition. Similarly, green technological progress is as essential as productive technological progress to ensure 
energy security and enhance international competitiveness. Therefore, facing the situation of increasing environmental pollution, scholars indicated that it is necessary to vigorously promote the progress of green technology and increase the technological content of exports. However, few studies have shown the relationship between high-tech product exports and low-carbon technological innovation. Based on these, the following hypothesis is proposed:

Hypothesis 3. (H3): Expanding the export trade of high-tech products is conducive to promoting low-carbon technological innovation.

Many studies have found evidence that trade liberalization improves enterprise production efficiency by increasing the accumulation of human capital. As an example, Mulliqi et al. (2019) used Tobit and Fractional Logit methods to prove that export companies can increase productivity by hiring more skilled and competent employees, and increasing the labor force with higher education will also reduce their relative costs and improve the international competitiveness of the company. Taking into account the needs of export companies for higher levels of human capital, scholars have also studied the relationship between export companies and human capital accumulation from different perspectives. From the perspective of export product structure, Blanchard and Olney (2017) showed that the export of skill-intensive products will increase the education level of the labor force, while the export of agricultural products and low-skill-intensive products will reduce the education level of the labor force. The reason for this phenomenon is that the growth of exports of skill-intensive enterprises will increase the demand for highly skilled talents, thereby promoting the improvement of the average education level of society. From the perspective of resource endowments, Hou and Karayalcin (2019) found that if an economy initially uses a large amount of resources for the production of primary products, the expansion of primary product exports will reduce the accumulation of human capital. From the perspective of different regions, Li et al. (2018) indicated that the level of human capital accumulation in regions dominated by high-tech 
product exports is higher than that in regions dominated by low-tech product exports, and the export shock of high-tech products will increase high school and university enrollment, while the export shock of low-tech products will restrain both. In addition, the scope of human capital is not only the education level of the labor force, but also includes the on-the-job training of employees, the work experience of senior managers and the accumulation of learning-by-doing (Mulliqi, 2019; Salim et al., 2017). Scholars have analyzed the demand for human capital in export trade from different aspects, but they have not showed clearly the relationship between the expansion of high-tech product exports and the accumulation of human capital in a region. Therefore, the following hypothesis is proposed:

Hypothesis 4. (H4): Expanding the export trade of high-tech products is conducive to human capital accumulation.

The relationship between industrial structure and regional carbon performance has been extensively researched. Scholars believe that the transformation of industrial structure is an important determinant of reducing industrial carbon dioxide emissions, especially for the situation where China's production and consumption structure has caused upward influences in changes of $\mathrm{CO}_{2}$ (Wang and Zhou, 2020; Tian et al., 2019). Data show that the three major industries and the secondary industry's carbon emissions reductions due to structural adjustment accounted for $28.22 \%$ and $4.26 \%$ of China's total carbon emissions reductions, respectively (Zhang et al., 2017). Industry is the main user of energy and an important contributor to global carbon dioxide emissions. From the transformation and upgrading of the internal structure of the industry, Xu et al. (2016) indicated that optimizing the structure of industrial enterprises is the top priority strategy for reducing carbon dioxide emissions in the region. From the perspective of the change of leading industries, Zhang and Ma (2020) stated that with the development of an economy, the transformation of industrial sectors from resource-intensive to labor-intensive and then to technology-intensive and capital-intensive is conducive to the decline of carbon emission intensity. 
Meanwhile, in the transformation of industrial structure, scholars have also realized the importance of the development of high-tech industries. Li et al. (2019) employed the STRIPAT-Dubin model of spatial panels with data on Chinese provinces to conclude that high-tech industries have an inhibitory effect on carbon emissions in both local and neighboring regions. Taking the comprehensive utilization of resources and environmental protection industries as examples, Xu and Lin (2018) discovered that the rapid development of high-tech industries is beneficial to the application of a plethora of energy-saving equipment and technologies such as waste power generation technology and automobile exhaust gas post-combustion technology. Although scholars have realized the importance of industrial structure transformation and the development of high-tech industries in reducing carbon emissions, they rarely see the impact of the general high-tech industry on regional carbon performance, that is, the relationship between industrial structure supererogation and regional carbon performance. Therefore, the following hypothesis is proposed:

Hypothesis 5. (H5): Industrial structure supererogation helps improve regional carbon performance.

Numerous scholars have validated the existence of the pollution haven hypothesis, and explained why China's large-scale export trade has led to China becoming a "pollution haven" (Sun et al., 2017; Solarin et al., 2017; Shahbaz et al., 2019). In this regard, Ren et al. (2014) indicated that low-carbon technology development contributes to averting China from being a pollution haven. The development direction of low-carbon technology includes renewable energy technology, energy-saving emission reduction technology, and decarbonization technology. For example, Khan et al. (2020) showed that increasing the proportion of renewable energy consumption to primary energy consumption is one of the effective ways to reduce carbon dioxide emissions. To achieve sustainable development, countries around the world are deploying environment-related innovations, such as renewable energy technologies. Nathaniel et al. (2020) also recommended that 
limiting the "dirty" energy sources and substituting them with renewable energy sources can promote environmental sustainability. Moreover, Zang et al. (2021) found that technological progress in production and energy conservation played a significant role in reducing industrial carbon emission intensity. The rapid economic growth in the early stages of the development of emerging economies is closely related to energy consumption, including in China and the Gulf Cooperation Council countries. Therefore, improving energy efficiency is very important. In this regard, Waheed et al. (2020) proposed that the decisive role of technology in improving energy efficiency is very interesting and innovative, allowing the latest technology and high-tech products becoming economic and environmental policy factors. Although the literature proposed the role of technological progress in reducing carbon emissions in many aspects, they did not consider the impact of low-carbon technological innovation on total regional carbon performance. The following hypothesis is proposed:

Hypothesis 6. (H6): Low-carbon technological innovation helps improve regional carbon performance.

Human capital is a key factor in enhancing economic competitiveness and achieving sustainable development. Sabadie (2014) pointed out that technology alone cannot achieve a green economy; skills are the basic conditions for future economic and social development. Therefore, this study considers the impact of industrial structure supererogation and low-carbon technological innovation on regional carbon performance, as well as the impact of human capital accumulation on carbon emissions. Household energy consumption awareness plays a decisive role in carbon emission reduction. Shahbaz et al. (2019) confirmed that the impact of education on energy demand is negative. They stated that in the United States, school education can increase household energy efficiency awareness, and educated people are willing to use new forms and new energy, thereby reducing energy consumption. Khan et al. (2020) believe that the higher the level of education, the more inclined to adopt a sustainable lifestyle someone would be. This view is consistent with the concept of 
the "energy culture" framework proposed by Stephenson et al. (2010). When consumers change their values, wishes, understandings and beliefs about the importance of energy, they will choose to purchase more efficient energy equipment, such as household heating equipment. From a company's internal perspective, company productivity and low-carbon awareness of companies play a key role in reducing carbon emissions. Cieplinski et al. (2020) proved that the reduction in working hours caused by the increase in labor productivity can help reduce carbon emissions. Abdelaziz et al. (2011) indicated that the low-carbon awareness of a company comes from the company's senior management; whether the company's senior management regularly participates in the plan of energy management projects to achieve energy management goals. For example, on the premise of not affecting production output and quality, energy costs and negative environmental impacts can be minimized. Based on the above analysis, it can be found that human capital accumulation is playing an increasingly important role in the development of the green economy, but the impact of human capital accumulation growth in a region on regional carbon performance has been rarely analyzed. Thus, the following hypothesis is proposed:

Hypothesis 7. (H7): The accumulation of human capital is conducive to improving carbon emissions.

\section{The mediating effect of industrial structure supererogation, low-c arbon technological innovation, and human capital accumulation}

Based on the above analysis, it can be seen that both the export trade of high-tech products and the supererogation of the industrial structure can help improve regional carbon performance, and the increase in export trade of high-tech products will promote the supererogation of the industrial structure. Therefore, it is believed that the impact of high-tech product trade on regional carbon performance is partly through the supererogation of the industrial structure as a transmission mechanism. Based on 
the analysis of the aforementioned hypotheses $\mathrm{H} 1, \mathrm{H} 2$, and $\mathrm{H} 5$, the following hypothesis is put forward:

Hypothesis 8. (H8): The supererogation of the industrial structure plays an intermediary role between the export trade of high-tech products and regional carbon performance.

The previous literature also found the important role of technology in the process of analyzing the impact of trade on the environment. Ali et al. (2017) revealed that the trade opening has led to a unidirectional increase in carbon emissions, while changes in trade patterns and energy-saving economic activities can help reduce carbon emissions. Therefore, governments and policy makers will need to focus on export-oriented trade and the upgrading of energy-related policies to ensure the use of new energy-efficient technologies. After comprehensively analyzing the hypotheses $\mathrm{H} 1, \mathrm{H} 3$, and $\mathrm{H} 6$, the following hypothesis is proposed:

Hypothesis 9. (H9): Low-carbon technological innovation plays a part of the intermediary role between the export trade of high-tech products and regional carbon performance.

Based on the analysis of hypotheses $\mathrm{H} 1, \mathrm{H} 4$, and $\mathrm{H} 7$, the following hypothesis is put forward:

Hypothesis 10. (H10): Human capital accumulation plays a part of the intermediary role between the export trade of high-tech products and regional carbon performance.

The theoretical model that underlies these hypotheses as a whole will be tested (see Figure 2). 


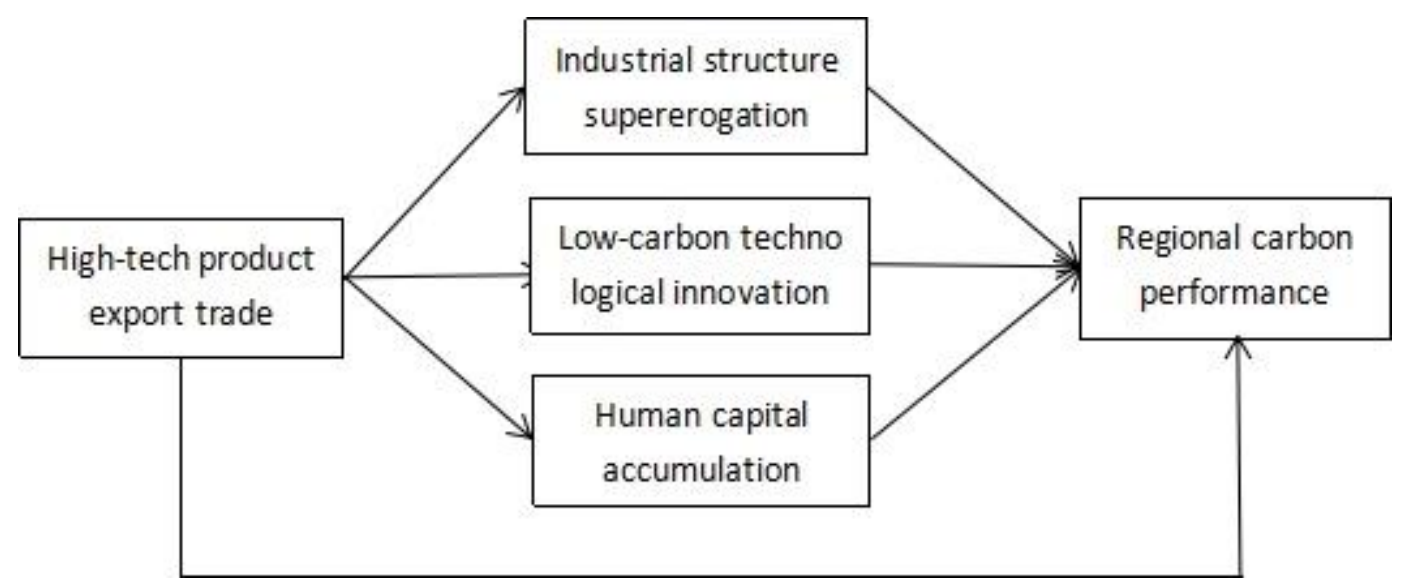

Fig.2 The impact path of high-tech product export trade on regional carbon performance

\section{Models, variables, and data}

\section{Model design}

\section{Direct effects model}

To verify hypothesis $\mathrm{H} 1$, the impact of high-tech product export trade on carbon emission intensity, this paper constructs the following basic panel data model:

$$
C I_{i t}=\alpha+\beta H_{-} e x_{i t}+\gamma_{j} \sum X_{i t j}+\varepsilon_{i t}
$$

Here, the explained variable $C I_{i t}$ represents the carbon emission intensity of province $\mathrm{i}$ in year $\mathrm{t}$, the explanatory variable $H_{-} e x_{i t}$ indicates the export trade of high-tech products of province $\mathrm{i}$ in year $\mathrm{t}, X_{i t j}$ indicates $\mathrm{j}$ control var iables, and $\boldsymbol{E}_{i t}$ is a random disturbance item.

\section{Mediating effect model}


To verify hypotheses $\mathrm{H} 2-\mathrm{H} 10$, we explore the role of high-tech product export trade on regional carbon performance, that is, whether high-tech product export trade promotes carbon emission reduction separately through the mechanisms of industrial structure supererogation, low-carbon technological innovation, and human capital accumulation mechanism. The investigation determines whether the indirect mechanism is significant in the mediation effect model. The test method is a simple but effective and improved stepwise method. So we introduced the mediating effect model (Baron and Kenny, 1986) into the following panel regressions.

$$
\begin{aligned}
& M_{i t}=\alpha+\beta_{2} H_{-} e x_{i t}+\gamma_{j} \sum X_{i t j}+\varepsilon_{i t} \\
& C I_{i t}=\alpha+\beta_{3} H_{-} e x_{i t}+\beta_{4} M_{i t}+\gamma_{j} \sum X_{i t j}{ }^{+} \varepsilon_{i t}
\end{aligned}
$$

Here, $M_{i t}$ represents the intermediary variables, which are industrial structure supererogation (IS), low-carbon technological innovation (patent), and human capital accumulation (HC).

\section{Variable definition}

\section{Explained variable: Carbon emission intensity (CI)}

Carbon emission intensity is a relative indicator of carbon emission reduction targets, measured by the proportion of total regional carbon emissions in GDP. Carbon emission intensity is an important indicator of low-carbon economic growth, reflecting carbon emissions and carbon source control capabilities from the perspective of economic structure. The smaller the carbon emission intensity, the greater the carbon emission reduction capability and the higher the regional carbon performance.

\section{Core explanatory variables and intermediate variables}


The core explanatory variable of this study is the export trade of high-tech products (H_ex), which is measured by the relative indicator of "the ratio of the export value of high-tech products to the total export value", and represents the upgrading of the export trade structure.

The intermediate variables are the following three: industrial structure supererogation (IS), low-carbon technological innovation (patent), and human capital accumulation (HC). Specifically, the industrial structure supererogation (IS) is expressed by the proportion of high-tech industry output value in industrial output value. Low-carbon technological innovation (patent) is characterized by the number of low-carbon patent applications per 10,000 people in the province that year. The human capital accumulation (HC) is expressed by the product of the education level and the years of education of employees in the province. The average cumulative years of education for various types of education are set to 0 years, 6 years, 9 years, 12 years, and 16 years (Barro, 2001).

\section{Control variables}

The degree of trade openness (open) uses the degree of trade dependence, expressed as the proportion of total import and export in the region's GDP. Foreign direct investment (FDI) is reflected by the proportion of the actual use of foreign direct investment in each province to the regional GDP to measure the impact of foreign capital inflows on the domestic economy under capital internationalization. Energy structure (ES) is measured by the proportion of coal consumption in total energy consumption. Energy structure is an important energy indicator in the low-carbon economic indicator evaluation system. Research investment (RD) is measured by the proportion of research and development expenditure in the gross regional product. Scientific research investment is an important technical indicator in the low-carbon economic indicator evaluation system. Environmental regulation (ER) 
is measured by selecting the proportion of environmental pollution control investment in the region's GDP.

\section{Data source and description}

\section{Statistical Yearbook and Patent Database}

The export trade of high-tech products and the output value of high-tech industries come from the China Science and Technology Statistical Yearbook. Based on the incomplete data on the output value and added value of high-tech industries in various provinces in the statistical yearbook, and given that the main business income determination is very close to the output value determination, the main business income data are used as a substitute for the output value. The data on the education level of employees in each province comes from the China Labor Statistics Yearbook. The investment in environmental pollution control comes from the China Environmental Statistical Yearbook. The data of low-carbon patent applications in each province comes from the incoPat patent database (" $\mathrm{CPC}=\mathrm{Y} 02$ "). The remaining data indicators come from the statistical yearbooks of provinces (autonomous regions and municipalities) from 2007 to 2018 . Due to restrictions on the availability of basic data in the Tibet Autonomous Region, Hong Kong, Macau, and Taiwan, in order not to affect the regression results, they were removed from the total sample and the data of the remaining 30 provincial administrative units in the mainland were retained.

\section{Calculation}

China's provincial carbon emissions data is not explicitly given in the statistical yearbook, but the data are obtained through calculations. Previous literature has pointed out that the total regional carbon emissions include emissions from fossil energy, cement manufacturing, steel, and textile industries, among which fossil energy emissions and cement manufacturing emissions account for more than 
three-quarters of the total carbon emissions. According to international statistical practices, emissions from industries such as steel and textiles are not considered. Therefore, the total carbon emissions in this study only include fossil energy consumption emissions and cement process emissions, and the total carbon emissions are calculated as the sum of the two sources. Regarding the carbon emissions caused by the burning of fossil energy, this paper mainly calculates the carbon emissions generated by the consumption of coal, oil, and natural gas. According to the IPCC formula and its improvements, the formula for calculating carbon emissions from the three primary energy consumption of coal, oil, and natural gas: $C E_{i t}=\sum_{j=1}^{3} E_{i t j} \theta_{j}$, where $\mathrm{CE}_{\mathrm{it}}$ represents the carbon emissions of the $\mathrm{i}$ province in year $\mathrm{t}, \mathrm{E}_{\mathrm{itj}}$ represents thephysical volume of the $\mathrm{j}$ energy consumption in the $\mathrm{i}$ province in year $\mathrm{t}, \mathrm{j}=1,2,3$, respectively representing coal, oil, and natural gas, $\theta_{\mathrm{j}}$ represents the carbon emission coefficient of $\mathrm{j}$ energy. The emission coefficients of various energy sources are shown in Table 1.

Table 1 Carbon emission coefficients of various types of energy

\begin{tabular}{llcc}
\hline $\begin{array}{l}\text { Energy type } \mathrm{j} \\
\text { coal }\end{array}$ & oil & natural gas \\
\hline $\begin{array}{l}\text { Carbon emission coefficient ( } \mathrm{t} \text { carbon/10,000 tons } \\
\text { of standard coal) } \theta \mathrm{j}\end{array}$ & 0.7476 & 0.5825 & 0.4435 \\
\hline
\end{tabular}

Source: Energy Research Institute of National Development and Reform Commission. China's sustainable development energy and carbon emission scenario analysis [R].2003.05

Secondly, the calculation formula for $\mathrm{CO} 2$ emissions during the cement industry production process: $C C_{i t}=P_{i t} \delta$, where $\mathrm{CC}_{\text {it }}$ represents the carbon emissions of $\mathrm{i}$ province in year $\mathrm{t}, \mathrm{P}_{\mathrm{it}}$ represents the cement industry production of i province in year $\mathrm{t}$, and $\delta$ represents the cement $\mathrm{CO}_{2}$ emission coefficient, the value is 0.376 . Then, 
$T C_{i t}=C E_{i t}+C C_{i t}$, where $\mathrm{TC}_{\mathrm{it}}$ is the total carbon emissions of i province in year t.

\section{Data description}

The variables' descriptive statistics are presented in Table 2.

Table 2 Descriptive statistics of variables

\begin{tabular}{cccccc}
\hline Variable category & variables & Mean & Std. Dev. & Min & Max \\
\hline Explained variable & CI & 0.940 & 0.651 & 0.12 & 4.26 \\
Explanatory variable & H_ex & 16.783 & 16.482 & 0.21 & 77.63 \\
& IS & 11.676 & 11.453 & 0.23 & 47.11 \\
Mediating variables & patent & 0.684 & 1.021 & 0.02 & 6.63 \\
& HC & 9.520 & 1.221 & 6.56 & 13.53 \\
& open & 0.369 & 0.476 & 0.01 & 3.34 \\
& FDI & 0.025 & 0.022 & 0.00 & 0.14 \\
Control variables & ES & 62.543 & 17.002 & 5.7 & 92.5 \\
& RD & 1.454 & 1.080 & 0.17 & 5.84 \\
& ER & 1.372 & 0.688 & 0.3 & 4.24 \\
\hline
\end{tabular}

\section{Results}

\section{Model selection and setting}

Before panel data use the measurement model to estimate the results, the model needs to be filtered. The results of the filtering are shown in Table 3. The individual effects result is significant at the $1 \%$ level, indicating that the fixed effects model is significantly better than the mixed effects model, rejecting the null hypothesis "the 
mixed effect model is valid". The time effects result also shows that it is significant at the $1 \%$ level, indicating that the random effects model is significantly better than the mixed effect model, rejecting the null hypothesis "the mixed effects model is valid". The Hausman test result is significant at the $1 \%$ level, meaning that the fixed effects model is better than the random effects model. The test result rejects the null hypothesis that "the random effects model is valid", so this study uses the fixed effects model to estimate the equation.

Table 3 Model selection and setting

\begin{tabular}{lllll}
\hline \multirow{2}{*}{ Test type } & \multicolumn{2}{l}{ Likelihood ratio test } & \multicolumn{2}{l}{ Hausman test } \\
\cline { 2 - 5 } & F statistic/chi-square value & P-value & F statistic & P-value \\
\hline individual effects & $40.5^{* * *}$ & 0.0000 & $48.83^{* * *}$ & 0.0000 \\
time effects & $601.54^{* * *}$ & 0.0000 & \\
\end{tabular}

$* * *, * *$, and $*$ denote $\mathrm{p}<0.01, \mathrm{p}<0.05$, and $\mathrm{p}<0.1$, respectively

\section{Analysis of regression results}

The regression analysis results of the fixed effects model are shown in Table 4. Model 1 in the table examines the impact of high-tech product export trade on carbon emissions intensity. The regression coefficient of high-tech product export trade is -0.016 and is significant at $1 \%$, indicating that high-tech product export trade has the effect of reducing carbon emission intensity, thus supporting Hypothesis 1. This result is similar to Liu et al. (2017), who suggested that optimizing the structure of the export and supply side to reduce the total carbon dioxide emission intensity. Model 2 examines the impact of high-tech product export trade on the supererogation of the industrial structure. The regression coefficient of high-tech product export trade is 0.571 and is significant at the $1 \%$ level, indicating that high-tech product export trade promotes the supererogation of the industrial structure, supporting Hypothesis 2. The regression coefficient of the industrial structure supererogation in Model 5 is -0.004 
and is significant at the level of $10 \%$, indicating that the industrial structure supererogation can reduce the carbon emission intensity, supporting Hypothesis 5, industrial structure supererogation is conducive to improving regional carbon performance. This finding is consistent with Wang and Zhou (2020) and Su et al. (2020), who showed that adjusting the production structure by promoting industrial upgrading contributes to carbon dioxide emissions reduction because the inhibition effect of structural change on carbon emissions presents an increasing marginal trend. The regression coefficient of high-tech product export trade in Model 5 is - -0.014 and is significant at the $1 \%$ level, indicating that the supererogation of the industrial structure has a partial mediating effect between high-tech product export trade and regional carbon performance. At the same time, in Model 5 the absolute value of the regression coefficient -0.014 of the export trade of high-tech products is smaller than the absolute value of -0.016 in Model 1 , which also confirms the validity of Hypothesis 8.

Model 3 examines the impact of high-tech product export trade on low-carbon technological innovation. The regression coefficient of high-tech product export trade is 0.008 and is significant at $1 \%$, indicating that high-tech product export trade promotes low-carbon technological innovation, supporting Hypothesis 3. The regression coefficient of low-carbon technological innovation in Model 6 is -0.186 and is significant at the $1 \%$ level, indicating that low-carbon technological innovation can reduce carbon emission intensity, supporting Hypothesis 6, low-carbon technological innovation is conducive to improving regional carbon performance. This result is consistent with the findings of Gu et al. (2020) that technological progress can effectively reduce carbon emission intensity, and strengthening the development of energy conservation and emission reduction technology patents will be conductive to achieving China's low-carbon development strategy. The regression coefficient of high-tech product export trade in Model 6 is -0.015 and is significant at the $1 \%$ level, indicating that low-carbon technological innovation plays a part in the 
mediating effect between high-tech product export trade and regional carbon performance. At the same time, in model 6 the absolute value of the regression coefficient -0.015 of the export trade of high-tech products is smaller than the absolute value of -0.016 in Model 1 , which also confirms the validity of the Hypothesis 9.

Model 4 examines the impact of high-tech product export trade on human capital accumulation. The regression coefficient of high-tech product export trade is 0.026 and is significant at $1 \%$, indicating that high-tech product export trade promotes human capital accumulation, supporting Hypothesis 4. The regression coefficient of human capital accumulation in Model 7 is -0.338 and is significant at the $1 \%$ level, indicating that human capital accumulation can reduce carbon emission intensity. This supports Hypothesis 7, human capital accumulation is conducive to improving regional carbon performance. The regression coefficient of high-tech product export trade in Model 7 is -0.007 and is significant at the $1 \%$ level, indicating that human capital accumulation has a partial mediating effect between high-tech product export trade and regional carbon performance. At the same time, in Model 7 the absolute value of the regression coefficient -0.007 of the export trade of medium and high-tech products is smaller than the absolute value of -0.016 in model 1 , which also confirms the validity of Hypothesis 10. These findings are consistent with those of Matyushenko et al. (2020), who showed that the ratio of the number of scientific and technical staff to the working population of the country is most influenced by high-tech exports of the country. 
Table 4 Regression analysis results of fixed effects model

\begin{tabular}{|c|c|c|c|c|c|c|c|}
\hline \multirow{3}{*}{$\begin{array}{c}\text { Explained } \\
\text { variable }\end{array}$} & Model & Model & Model & Model & Model & Model & Model \\
\hline & 1 & 2 & 3 & 4 & 5 & 6 & 7 \\
\hline & CI & IS & patent & $\mathrm{HC}$ & CI & CI & CI \\
\hline \multicolumn{8}{|l|}{$\begin{array}{c}\text { Core } \\
\text { explanatory } \\
\text { variable }\end{array}$} \\
\hline H_ex & $\begin{array}{c}-0.016^{* * *} \\
(0.002)\end{array}$ & $\begin{array}{c}0.571^{* * * *} \\
(0.037)\end{array}$ & $\begin{array}{l}0.008^{* * * *} \\
(0.003)\end{array}$ & $\begin{array}{c}0.026^{* * * *} \\
(0.003)\end{array}$ & $\begin{array}{c}-0.014^{* * *} \\
(0.002)\end{array}$ & $\begin{array}{c}-0.015^{* * *} \\
(0.001)\end{array}$ & $\begin{array}{c}-0.007^{* * *} \\
(0.001)\end{array}$ \\
\hline
\end{tabular}

Mediating

variables

IS

$-0.004^{*}$

$(0.002)$

patent

$-0.186^{* * *}$

(0.033)

$\mathrm{HC}$

$$
\begin{gathered}
-0.338^{* * *} \\
(0.028)
\end{gathered}
$$

\section{Control}

variables

$$
\begin{array}{lccccccc} 
& 0.102^{*} & 3.695^{* *} & -0.140 & 0.061 & 0.119^{*} & 0.076 & 0.123^{* *} \\
& (0.060) & (1.442) & (0.099) & (0.101) & (0.061) & (0.058) & (0.050) \\
& & & & & & & \\
\text { FDI } & 9.186^{* * *} & -93.711^{* * *} & -6.279^{* * *} & -16.496^{* * *} & 8.775^{* * *} & 8.017^{* * *} & 3.617^{* * *} \\
& (1.294) & (30.914) & (2.130) & (2.175) & (1.307) & (1.250) & (1.161) \\
& & & & & & & \\
\text { ES } & 0.006^{* *} & 0.164^{* *} & -0.035^{* * *} & -0.027^{* * *} & 0.007^{* *} & -0.001 & -0.003 \\
& (0.003) & (0.067) & (0.005) & (0.005) & (0.003) & (0.003) & (0.002) \\
& & & & & & & \\
\text { RD } & 0.084 & 12.327^{* * *} & 0.715^{* * *} & 0.660^{* * *} & 0.138^{* *} & 0.217^{* * *} & 0.307^{* * *} \\
& (0.060) & (1.433) & (0.099) & (0.101) & (0.066) & (0.062) & (0.053)
\end{array}
$$

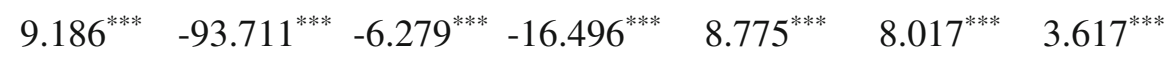

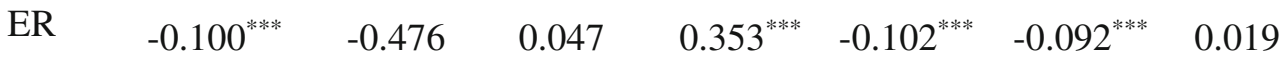




\begin{tabular}{llllllll} 
& $(0.035)$ & $(0.839)$ & $(0.058)$ & $(0.059)$ & $(0.035)$ & $(0.033)$ & $(0.031)$ \\
$\mathrm{R}^{\wedge} 2$ & 0.382 & 0.5194 & 0.4331 & 0.5533 & 0.3888 & 0.4402 & 0.5811 \\
\hline
\end{tabular}

$\overline{\text { Coefficient standard errors are shown in parentheses; } * * *, * * \text {, and } * \text { denote } \mathrm{p}<0.01, \mathrm{p}<0.05}$, and $\mathrm{p}<0.1$,respectively

Based on the aforementioned analysis, it is concluded that the export trade of high-tech products affects performance through three parallel paths of industrial structure supererogation, low-carbon technological innovation, and human capital accumulation. For the sake of improving the credibility of the statistical results, the following will verify the effect of multiple intermediaries through the bootstrap repeated sampling method. The bootstrap process samples the sample 2000 times, and the results are shown in Table 5.

Table 5 Bootstrap test of the mediating effects

\begin{tabular}{lcccc}
\hline \multirow{2}{*}{ Mediating variables } & Coef. & Std. Err. & \multicolumn{2}{l}{$95 \%$ Conf. Interval } \\
\cline { 4 - 5 } & & & Lower limit & Upper limit \\
\hline industrial structure supererogation & -0.1758 & 0.0318 & -0.2380 & -0.1135 \\
low-carbon technological innovation & -0.0581 & 0.0182 & -0.0938 & -0.0224 \\
human capital accumulation & -0.0224 & 0.0092 & -0.0405 & -0.0043 \\
\hline
\end{tabular}

According to the results displayed in Table 5, the effect of industrial structure supererogation on the relationship between high-tech product export trade and regional carbon performance is -0.1758 (95\% confidence interval does not include 0 ). Therefore, the mediating role of industrial structure supererogation between the export trade of high-tech products and regional carbon performance is established, and Hypothesis 8 has been verified. In the same way, the mediating role of low-carbon technological innovation between the export trade of high-tech products 
and regional carbon performance is established, and Hypothesis 9 is verified. The mediating role of human capital accumulation between the export trade of high-tech products and regional carbon performance is established, and Hypothesis 10 is verified.

\section{Robustness test}

\section{Sensitivity test}

To examine the robustness of the results, the explanatory variable carbon emission intensity is replaced, and per capita carbon emissions is selected as the explained variable to test the impact of high-tech product export trade on regional carbon performance. The sensitivity test results are shown in Table 6. According to the regression coefficients and significance in the table, it can be seen that the assumptions $\mathrm{H} 1-\mathrm{H} 10$ are all valid, as they remain consistent with the regression results of the fixed effects model mentioned above. The export trade of high-tech products facilitates a per capita reduction of carbon emissions through industrial structure supererogation, low-carbon technological innovation, and human capital accumulation. That is, industrial structure supererogation, low-carbon technological innovation, and human capital accumulation have partial mediating effects in the link between the export trade of high-tech products and regional carbon performance. It can be seen that the test results are robust.

Table 6 Sensitivity test results

\begin{tabular}{cccccccc}
\hline \multirow{2}{*}{$\begin{array}{c}\text { Explained } \\
\text { variable }\end{array}$} & Model & Model & Model & Model & Model & Model & Model \\
\cline { 2 - 8 } & & 2 & 3 & 4 & 5 & 6 & 7 \\
\hline
\end{tabular}

\section{Core}

explanatory 
variable

$$
\begin{array}{lcllllll} 
& -0.392^{\text {**** }} & 0.571^{* * * *} & 0.008^{* * * *} & 0.026^{* * * *} & -0.366^{* * *} & -0.319^{* * *} & -0.051^{* * * *} \\
\text { H_ex } & (0.074) & (0.037) & (0.003) & (0.003) & (0.072) & (0.065) & (0.017)
\end{array}
$$

Mediating

variables

IS

$$
\begin{aligned}
& -0.879^{* * *} \\
& (0.189)
\end{aligned}
$$

patent

$-0.044^{* * * *}$

(0.004)

HC

$-10.745^{* * *}$

(0.918)

Control

variables

$\begin{array}{cccccccc} & 0.058 & 3.695^{* *} & -0.140 & 0.061 & 0.050 & -0.010 & 0.001 \\ \text { open } & (0.105) & (1.442) & (0.099) & (0.101) & (0.102) & (0.092) & (0.001)\end{array}$

FDI

$$
\begin{array}{lllllll}
-9.726^{* * *} & -93.711^{* * *} & -6.279^{* * *} & -16.496^{* * *} & -8.422^{* * *} & -5.029^{* *} & -0.172
\end{array}
$$

$\begin{array}{lllllll}(2.246) & (30.914) & (2.130) & (2.175) & (2.193) & (2.016) & (0.188)\end{array}$

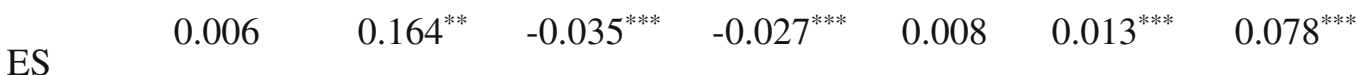

$\begin{array}{lllllll}(0.005) & (0.067) & (0.005) & (0.005) & (0.005) & (0.004) & (0.014)\end{array}$

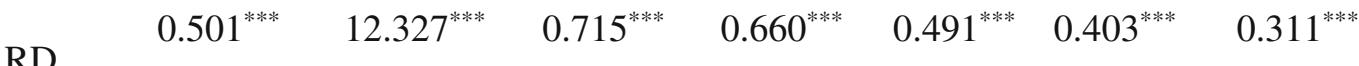

$\begin{array}{lllllll}(0.104) & (1.433) & (0.099) & (0.101) & (0.101) & (0.091) & (0.065)\end{array}$

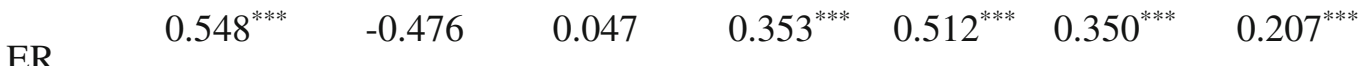

$\begin{array}{lllllll}(0.061) & (0.839) & (0.058) & (0.059) & (0.060) & (0.057) & (0.037)\end{array}$

$\begin{array}{llllllll}\mathrm{R}^{\wedge} 2 & 0.3557 & 0.5194 & 0.4331 & 0.5533 & 0.3975 & 0.5109 & 0.5735\end{array}$

Coefficient standard errors are shown in parentheses; $* * *, * *$, and $*$ denote $\mathrm{p}<0.01, \mathrm{p}<0.05$, and $\mathrm{p}<0.1$,respectively

\section{Replacement of test methods}


Endogenous issues are important issues that should be considered in regression analysis. However, because it is impossible to put all the factors that affect regional carbon performance into the control variables, some variables will be omitted. At the same time, there may be a two-way causal relationship between variables, which will lead to the emergence of endogenous problems. Therefore, to avoid differences in regression results due to different regression methods, method replacement will be used for robustness testing. Based on the basic regression in this study, the static panel data fixed effects model is used for regression. The dynamic panel data regression system GMM model will be used to estimate the impact of high-tech product export trade on regional carbon performance. The estimated results are shown in Table 7. 
Table 7 Robustness test results of method replacement

\begin{tabular}{|c|c|c|c|c|c|c|c|}
\hline \multirow{3}{*}{$\begin{array}{l}\text { Explained } \\
\text { variable }\end{array}$} & Model & Model & Model & Model & Model & Model & Model \\
\hline & 1 & 2 & 3 & 4 & 5 & 6 & 7 \\
\hline & $\mathrm{CI}$ & IS & patent & $\mathrm{HC}$ & $\mathrm{CI}$ & $\mathrm{CI}$ & $\mathrm{CI}$ \\
\hline \multicolumn{8}{|l|}{ The first-order } \\
\hline $\begin{array}{c}\text { lag of } \\
\text { explained } \\
\text { variable }\end{array}$ & $\begin{array}{l}0.874^{* * *} \\
(0.017)\end{array}$ & $\begin{array}{l}0.850^{* * *} \\
(0.015)\end{array}$ & $\begin{array}{l}0.961^{* * *} \\
(0.002)\end{array}$ & $\begin{array}{l}0.834^{* * *} \\
(0.022)\end{array}$ & $\begin{array}{l}0.809^{* * *} \\
(0.007)\end{array}$ & $\begin{array}{l}0.838^{* * *} \\
(0.008)\end{array}$ & $\begin{array}{c}0.878^{* * *} \\
(0.023)\end{array}$ \\
\hline \multicolumn{8}{|l|}{$\begin{array}{c}\text { Core } \\
\text { explanatory } \\
\text { variable }\end{array}$} \\
\hline H_ex & $\begin{array}{c}-0.028^{* * *} \\
(0.008)\end{array}$ & $\begin{array}{l}0.151^{* * *} \\
(0.010)\end{array}$ & $\begin{array}{c}0.002^{* * *} \\
0.000\end{array}$ & $\begin{array}{c}0.014^{* * * *} \\
(0.003)\end{array}$ & $\begin{array}{l}-0.019^{* * *} \\
(0.003)\end{array}$ & $\begin{array}{l}-0.017^{* * *} \\
(0.005)\end{array}$ & $\begin{array}{c}-0.017^{* * * *} \\
(0.003)\end{array}$ \\
\hline
\end{tabular}

Mediating

variables

IS

$$
\begin{aligned}
& -0.003^{* * *} \\
& (0.000)
\end{aligned}
$$

patent

HC

Control

variables

$\begin{array}{lccccccc} & -0.031 & 1.004^{* * *} & 0.085^{* * *} & 0.007^{* *} & 0.003 & -0.017^{* * *} & 0.009^{*} \\ & (0.019) & (0.403) & (0.006) & (0.003) & (0.010) & (0.005) & (0.005) \\ & & & & & & & \\ \text { FDI } & 0.953 & 21.502^{* *} & -2.265^{* * *} & -0.003 & 1.276^{* * *} & 1.206^{* * *} & 0.102^{* * *} \\ & (0.751) & (10.098) & (0.322) & (0.004) & (0.281) & (0.252) & (0.049) \\ & & & & & & & \\ \text { ES } & -0.0002 & -0.0004 & -0.005^{* * *} & -0.026^{* * *} & -0.147^{* * *} & -0.136^{* * *} & -0.021 \\ & (0.0005) & (0.013) & (0.0003) & (0.007) & (0.024) & (0.028) & (0.013) \\ \text { RD } & & & & & & & \\ & -0.022 & 1.284^{* * * *} & 0.106^{* * *} & -0.011^{* * *} & 0.147^{* * *} & 0.117^{* * *} & -0.002\end{array}$




\begin{tabular}{ccccccccc} 
& $(0.014)$ & $(0.221)$ & $(0.004)$ & $(0.009)$ & $(0.010)$ & $(0.012)$ & $(0.016)$ \\
& & & & & & & \\
ER & $0.023^{* * *}$ & $1.265^{* * *}$ & $-0.029^{* * *}$ & $0.017^{* * *}$ & 0.006 & $0.022^{* * *}$ & 0.002 \\
& $(0.004)$ & $(0.146)$ & $(0.004)$ & $(0.004)$ & $(0.008)$ & $(0.006)$ & $(0.004)$ \\
AR(2) & 0.4943 & 0.7083 & 0.1399 & 0.2616 & 0.8695 & 0.7834 & 0.7549 \\
Sargan & 1 & 1 & 1 & 1 & 1 & 1 & 1 \\
\hline
\end{tabular}

Coefficient standard errors are shown in parentheses; $* * *, * *$, and $*$ denote $\mathrm{p}<0.01, \mathrm{p}<0.05$, and $\mathrm{p}<0.1$,respectively

The AR(2) test results in models 1-7 show that they all pass the significance test at the 5\% level, indicating that the model does not have serial correlation problems. The results of a Sargan test show that the selected instrumental variables are all valid. The results confirm that the hypotheses $\mathrm{H} 1-\mathrm{H} 10$ are established, meaning that the research results are not affected by the research methods. Also, in the first-order lagged term of the explained variable, the carbon emission intensity of the lagging period has a positive correlation with the carbon emission intensity of the current period, and it is significant at the level of $1 \%$. This indicates that the issue of regional carbon performance improvement is not a short-term temporary problem, but has a certain law of inertia. Therefore, strong measures should be taken to improve regional carbon performance.

In summary, we conclude that (1) the export trade of high-tech products has a significant positive impact on local carbon performance, and (2) in the intermediary effect test, the export trade of high-tech products has a positive effect on industrial structure supererogation, low-carbon technological innovation and human capital accumulation, and industrial structure supererogation, low-carbon technological innovation and human capital accumulation have positive effects on local carbon performance. Therefore, high-tech product export trade indirectly improves local carbon performance through industrial structure supererogation, low-carbon technological innovation, and human capital accumulation. 


\section{Conclusions and policy implications}

This research innovatively analyzes the mechanisms of expanding the export of high-tech products to improve regional carbon performance, and came to the conclusion that expanding the export trade of high-tech products not only reduces embodied carbon emissions through direct effects, but also reduces total regional carbon emissions through industrial structure supererogation, low-carbon technological innovation and human capital accumulation. Understanding the mechanisms by which the export trade of high-tech products affects regional carbon performance has important theoretical and practical significance. On the one hand, it expands the endogenous power of the impact of high-tech product exports on regional carbon performance, and provides theoretical support for further expansion of high-tech product exports, industrial structure supererogation, low-carbon technological innovation, and human capital accumulation. On the other hand, it helps to reduce the negative environmental impact and energy resource loss caused by the long-term export trade of high energy consumption and low-tech products, improve China's position in the global value chain division of labor, and promote China's low-carbon economic transformation. These findings are similar to those of $\mathrm{Hu}$ et al. (2020) and Li et al. (2018), who indicated that reducing energy consumption-intensive but low value-added exports and developing high-tech industries, promoting cleaner production technology are important for promoting sustainable development. The green transformation of export trade and the realization of China's provincial sustainable development goals can, therefore, be improved by expanding the proportion of high-tech product export trade in the total regional export trade, thereby improving industrial structure supererogation, low-carbon technological innovation, human capital accumulation and regional carbon performance. Moreover, since China could be regarded as a model for developing countries, the conclusions of our study are helpful for other developing countries to get rid of becoming "pollution havens". 
To expand the impact of high-tech product export trade on improving regional carbon performance, this study proposes policy recommendations. First, while vigorously developing the export trade of high-tech products, the export of high-tech products should be developed diversely and comprehensively. Enhancing the technical make-up of high-tech products will help improve China's position in the division of labor in the global value chain, promote the transformation of export trade from quantity to quality, and accelerate the upgrading of the export trade structure. In addition, the long-standing imbalance in China's high-tech product export structure may become a bottleneck in the vigorous development of high-tech product exports. Therefore, high-tech product exports should be developed in a diversified and comprehensive manner. Meanwhile, to increase the enthusiasm of export enterprises to comprehensively develop the export of high-tech products, governments at all levels should set up special funds to guide and encourage export enterprises to invest in the export trade of high-tech products. Second, giving play to the intermediary role of industrial structure supererogation, low-carbon technological innovation, and human capital accumulation, local governments should accelerate the construction of high-tech industrial parks, accelerate the development of high-tech industries through the use of technology spillover effects of high-tech industries, and drive the transformation and upgrading of traditional industries. The government should encourage and subsidize enterprises, scientific research institutes, colleges and universities that conduct research and development of low-carbon technology innovation to accelerate the development and universal application of low-carbon technology. Ben Youssef (2020) also proposed that local governments should provide administrative facilities and R\&D grants for the creation and use of technological patents. Local governments and schools should increase investments in education, increase the level of human capital, and raise the awareness of energy efficiency among households. Furthermore, colleges should expand the enrollment and training of higher technical majors, strengthen the construction of industry-university-research 
cooperation bases with local governments and enterprises to boost technological innovation capabilities, and give priority to the role of talents, knowledge, technology, and industry in the development of the green economy. Besides, to prevent the "drain of minds", governments need to develop incentive measures to retain specialists at home (Matyushenko et al., 2020). Third, learning from the advanced experience of international export trade development, governments at all levels should incorporate energy efficiency and other factors affecting carbon emissions consumption into the design stage of technical products, and promote environmentally-friendly investments. Governments should improve the energy tax system. A sound energy tax system is conducive to mitigating the impact of energy on the environment. This forces the industry to adopt advanced environmental protection technologies, renewable energy technologies, and accelerate industrial upgrading and transformation as well as the systematic training of human capital to enhance national competitiveness and sustainable economic development.

There are still deficiencies in this study. On the one hand, limited by the unavailability of data, the sample period is relatively short. The supplement of the sample can be used to test the stability of the impact of the development of high-tech product export trade on regional carbon emissions. On the other hand, due to the limitation of the length of the article, there is no comparative analysis of the impact of carbon emissions reduction in the three major economic regions of the East, Central, and West and highlighting their different stages of industrialization. Further research can be done in these areas.

Authors' contributions Data collection and curation, formal analysis, writing-original draft and editing were performed by Miao Han. Methodology and writing-review were performed by Yan Zhou.

Funding The authors received no financial support for the research. 
Data availability The datasets used in this study are available from the corresponding author on reasonable request.

\section{Ethical Approval}

This manuscript is original and is neither under consideration elsewhere nor has it been published previously in whole or in part.

The Results are presented clearly, honestly, and without fabrication, falsification or inappropriate data manipulation.

No data, text, or theories by others are presented as if they were the author's own.

\section{Compliance with ethical standards}

Conflicts of interest The authors declare that they have no conflicts of interest.

Consent to participate We confirm that the manuscript has been read and approved by all named authors and that there are no other persons who satisfied the criteria for authorship but are not listed. We further confirm that the order of authors listed in the manuscript has been approved by all of us.

Consent to publish The authors agree to publish this article in the Environmental Science and Pollution Research.

\section{References}

Abdelaziz EA, Saidur R, Mekhilef S. (2011). A review on energy saving strategies in industrial sector. Renewable and Sustainable Energy Reviews, 15(1):150-168. http s://doi.org/10.1016/j.rser.2010.09.003

Ali W, Abdullah A, Azam M. (2017). The dynamic relationship between structural ch ange and $\mathrm{CO} 2$ emissions in Malaysia: a cointegrating approach. Environmental Sci ence and Pollution Research, 24(14):12723-12739. https://doi.org/10.1007/s11356-01 $\underline{7-8888-6}$ 
Babatunde KA, Said FF, Md Nor NG, Begum RA, Mahmoud MA. (2020). Coherent or conflicting? Assessing natural gas subsidy and energy efficiency policy interacti ons amid $\mathrm{CO}_{2}$ emissions reduction in Malaysia electricity sector. Journal of Cleane r Production, 279:Paper 123374. https://doi.org/10.1016/j.jclepro.2020.123374

Baron RM, Kenny DA. (1986). The Moderator-Mediator Variable Distinction in Social Psychological Research: Conceptual, Strategic, and Statistical Considerations. Journ al of Personality and Social Psychology, 51(6):1173-1182. https://doi.org/10.1037/0 $\underline{022-3514.51 .6 .1173}$

Barro RJ, Lee JW. (2001). International data on educational attainment: updates and i mplications. Oxford Economic Papers-New series, 53(3):541-563. https://doi.org/10. 1093/oep/53.3.541

Ben Youssef, S. (2020). Non-resident and resident patents, renewable and fossil energy, pollution, and economic growth in the USA. Environmental Science and Pollution Research, 27(32):40795-40810. https://doi.org/10.1007/s11356-020-10047-0

Benkovskis K, Masso Jaan, Tkacevs Olegs. Export and productivity in global value cha ins: comparative evidence from Latvia and Estonia. Review of World Economics, 156(3):557-577. https://doi.org/10.1007/s10290-019-00371-0

Blanchard EJ, Olney WW. (2017). Globalization and human capital investment: expor $\mathrm{t}$ composition drives educational attainment. Journal of International Economics, 1 06:165-183. https://doi.org/10.1016/j.jinteco.2017.03.004

Cieplinski A, D'Alessandro S, Guarnieri P. (2021). Environmental impacts of productiv ity-led working time reduction. Ecological Economics, 179:Paper 106822. https://d oi.org/10.1016/j.ecolecon.2020.106822

Cole MA. (2006). Does trade liberalization increase national energy use? Economics L etters, 92(1):108-112. https://doi.org/10.1016/j.econlet.2006.01.018

Dong HM, Xue MG, Xiao, YJ. (2020). Do carbon emissions impact the health of resi dents? Considering China's industrialization and urbanization. Science of the Total Environment, 758:paper 143688. https://doi.org/10.1016/j.scitotenv.2020.143688

Esquivias MA, Harianto SK. (2020). Does competition and foreign investment spur in dustrial efficiency?: firm-level evidence from Indonesia. Heliyon, 6(8):Paper e0449 4. https://doi.org/10.1016/j.heliyon.2020.e04494

Gu W, Chu ZZ, Wang C. (2020). How do different types of energy technological pro gress affect regional carbon intensity? A spatial panel approach. Environmental Sc ience and Pollution Research, 27(35):44494-44509. https://doi.org/10.1007/s11356-0 $\underline{20-10327-9}$ 
Hou YL, Karayalcin C. (2019). Exports of primary goods and human capital accumula tion. Review of International Economics, 27(5):1371-1408. https://doi.org/10.1111/r oie. 12428

Hu MM, Chen SQ, Wang YF. (2021). Identifying the key sectors for regional energy, water and carbon footprints from production-, consumption- and network-based per spectives. The Science of the total environment, 764:Paper 142821. https://doi.org/ 10.1016/j.scitotenv.2020.142821

Isik M, Dodder R, Ozge KP. (2021). Transportation emissions scenarios for New Yor $\mathrm{k}$ City under different carbon intensities of electricity and electric vehicle adoptio n rates. Nature Energy, 6(1):92-104. https://doi.org/10.1038/s41560-020-00740-2

Jena D, Barua A. (2020). Trade, structural transformation and income convergence: Th e case of EU. Journal of Public Affairs, Paper e2565. https://doi.org/0.1002/pa.256 $\underline{5}$

Kahrl F, Roland-holst D. (2008). Energy and exports in China. China Economic Revie w, 19(4):649-658. https://doi.org/10.1016/j.chieco.2008.05.004

Khan Z, Ali S, Umar M, Kirikkaleli D, Jiao ZL. (2020). Consumption-based carbon emissions and international trade in G7 countries: the role of environmental innov ation and renewable energy. Science of the Total Environment, 730:paper 13894. https://doi.org/10.1016/j.scitotenv.2020.138945

Li L, Hong XF, Peng K. (2018). A spatial panel analysis of carbon emissions, econo mic growth and high-technology industry in China. Structural Change and Econo mic Dynamics, 49:83-92. https://doi.org/10.1016/j.strueco.2018.09.010

Liddle, B. (2017). Consumption-based accounting and the trade-carbon emissions nexus. Energy Economics, 69:71-78. https://doi.org/10.1016/j.eneco.2017.11.004

Liu ZY, Mao XQ, Song P. (2017). GHGs and air pollutants embodied in China's international trade: Temporal and spatial index decomposition analysis. Plos One, 12(4):Paper e0176089. https://doi.org/10.1371/journal.pone.0176089

Matyushenko I, Hlibko S, Petrova MM. (2020). Assessment of the development of for eign trade in high-tech production of Ukraine under the association with the EU. Business Management and Education, 18(1):157-182. https://doi.org/10.3846/bme.20 $\underline{20.11578}$

Mazzi CT, Foster-McGregor N, Ferreira, GED. (2020). Production fragmentation and u pgrading opportunities for exporters: An empirical assessment of the case of Brazi 1. World Development, 138:Paper 105151. https://doi.org/10.1016/j.worlddev.2020.1 $\underline{05151}$ 
Mulliqi A, Adnett N, Hisarciklilar M. (2019). Human capital and exports: a micro-lev el analysis of transition countries. The Journal of International Trade \& Economic Development, 28(7):775-800. https://doi.org/10.1080/09638199.2019.160331

$\mathrm{Na}$ H. (2019.) Is intraregional trade an opportunity for industrial upgrading in East Af rica? Oxford Development Studies, 47(3):304-318. https://doi.org/10.1080/13600818. $\underline{2019.1570105}$

Nathaniel S, Aguegboh E, Iheonu, C, Sharma G, Shah MH. (2020). Energy consumpt ion, FDI, and urbanization linkage in coastal Mediterranean countries: re-assessingt he pollution haven hypothesis. Environmental Science and Pollution Research, 27 (28):35474-35487. https://doi.org/10.1007/s11356-020-09521-6

Perla J, Tonetti C, Waugh ME. (2015). Equilibrium Technology Diffusion, Trade, an d Growth. American Economic Review, 111(1):73-128. https://doi.org/10.1257/aer2 $\underline{0151645}$

Ren SG, Yuan BL, Ma X. (2014). The impact of international trade on China's indust rial carbon emissions since its entry into WTO. Energy Policy, 69:624-634. http:// dx.doi.org/10.1016/j.enpol.2014.02.032

Sabadie JA. (2014). Technological innovation, human capital and social change for sus tainability. Lessons learnt from the Industrial Technologies Theme of the EU's Re search Framework Programme. Science of the Total Environment, 481:668-673. htt ps://dx.doi.org/10.1016/j.scitotenv.2013.09.082

Sadorsky P. (2011). Trade and energy consumption in the Middle East. Energy Econo mics, 33(5):739-749. https://doi.org/10.1016/j.eneco.2010.12.012

Salim R, Yao Y, Chen G. (2017). Does human capital matter for energy consumption in China? Energy Economics, 67:49-59. https://doi.org/10.1016/j.eneco.2017.05.016

Shabani E, Hayati B, Pishbahar E, Ghorbani MA, Ghahremanzadeh M. (2020). A nov el approach to predict $\mathrm{CO}_{2}$ emission in the agriculture sector of Iran based on In clusive Multiple Model. Journal of Cleaner Production, 279:paper 123708. https://d oi.org/10.1016/j.jclepro.2020.123708

Shahbaz M, Gozgor G, Hammoudeh S. (2019). Human capital and export Diversificati on as new determinants of energy demand in the United States. Energy Economic s, 78:335-349. https://doi.org/10.1016/j.eneco.2018.11.016

Shahzad U, Dogan B, Sinha A. (2020). Does Export product diversification help to re duce energy demand: Exploring the contextual evidences from the newly industria lized countries. Energy, 214:paper 118881. https://doi.org/10.1016/j.energy.2020.118 $\underline{881}$

Shao WB, Li FY, Cao, X.. (2020). Reducing export-driven $\mathrm{CO}_{2}$ and PM emissions in China's provinces: A structural decomposition and coordinated effects analysis. Jo 
urnal of Cleaner Production, 274:paper 123101. https://doi.org/10.1016/j.jclepro.202 $\underline{0.123101}$

Solarin SA, Al-Mulali U, Musah I. (2017). Investigating the Pollution Haven Hypothes is in Ghana: An Empirical Investigation. Energy, 124:706-719. https://doi.org/10.10 16/j.energy.2017.02.089

Song ML, Wang SH. (2017). Market competition, green technology progress and com parative advantages in China. Management Decision, 56(1):188-203. https://doi.org/ 10.1108/MD-04-2017-0375

Stephenson J, Barton B, Carrington Gerry. (2010). Energy cultures: A framework for understanding energy behaviours. Energy Policy, 38(10):6120-6129. https://doi.org/1 $\underline{0.1016 / j . e n p o l .2010 .05 .069}$

Su B, Thomson E. (2016). China's carbon emissions embodied in (normal and process ing) exports and their driving forces, 2006-2012. Energy Economics, 59:414-422. https://doi.org/10.1016/j.eneco.2016.09.006

Su YQ, Liu X, Ji JP. (2020). Role of economic structural change in the peaking of China's $\mathrm{CO}_{2}$ emissions: An input-output optimization model. Science of the Total Environment, 761:Paper 143306. https://doi.org/10.1016/j.scitotenv.2020.143306

Sun CW, Zhang F, Xu M. (2017). Investigation of pollution haven hypothesis for Chi na: An ARDL approach with breakpoint unit root tests. Journal of Cleaner Produ ction, 161:153-164. http://dx.doi.org/10.1016/j.jclepro.2017.05.119

Tian K, Dietzenbacher E, Jong-A-Pin R. (2019). Measuring industrial upgrading: apply ing factor analysis in a global value chain framework. Economic Systems Researc h, 31(4):642-664. https://doi.org/10.1080/09535314.2019.1610728

Waheed R, Sarwar S, Mighri Z. (2020). Role of high technology exports for energy e fficiency: Empirical evidence in the context of Gulf Cooperation Council countries. Energy \& Environment, Paper 0958305X20954196. https://doi.org/10.1177/0958305 $\underline{\mathrm{X} 20954196}$

Wang SH, Tang Y, Du ZH, Song ML. (2020). Export trade, embodied carbon emissio ns,and environmental pollution: An empirical analysis of China's high- and new-te chnology industries. Journal of Environmental Management, 276:Paper 111371. htt ps://doi.org/10.1016/j.jenvman.2020.111371

Wang Q, Wang SS. (2020). Preventing carbon emission retaliatory rebound post-COVI D-19 requires expanding free trade and improving energy efficiency. Science of $t$ he Total Environment, 746:Paper 141158. https://doi.org/10.1016/j.scitotenv.2020.14 $\underline{1158}$

Wang YM, Xin L. (2020). The impact of China's trade with economies participating in the Belt and Road Initiative on the ecological total factor energy efficiency of 
China's logistics industry. Journal of Cleaner Production, 276:Paper 124196. https: //doi.org/10.1016/j.jclepro.2020.124196

Wang QY, Zhao CY. (2020). Regional difference and driving factors of industrial carb on emissions performance in China. Alexandria Engineering Journal, 60(1):301-309. https://doi.org/10.1016/j.aej.2020.08.009

Wang Q, Zhou YL. (2020). Evolution and drivers of production-based carbon emission $\mathrm{s}$ in China and India: Differences and similarities. Journal of Cleaner Production, 277:Paper 123958. https://doi.org/10.1016/j.jclepro.2020.123958

Weber CL, Peters GP, Guan D, Hubacek K (2008) The contribution of Chinese expor ts to climate change. Energy Policy 36(9):3572-3577. https://doi.org/10.1016/j.enpol. $\underline{2008.06 .009}$

Weber S, Gerlagh R, Mathys NA. (2021). $\mathrm{CO}_{2}$ embodied in trade: trends and fossil $\mathrm{f}$ uel drivers. Environmental Science and Pollution Research. https://doi.org/10.1007/s $\underline{11356-020-12178-\mathrm{w}}$

Xu M, Allenby B, Chen WQ. (2009). Energy and Air Emissions Embodied in ChinaU.S. Trade: Eastbound Assessment Using Adjusted Bilateral Trade Data. Environm ental Science \& Technology, 43(9):3378-3384. https://doi.org/10.1021/es803142v

$\mathrm{Xu} \mathrm{B}$, Lin BQ. (2018). Investigating the role of high-tech industry in reducing China's $\mathrm{CO}_{2}$. Journal of Cleaner Production, 177:169-177. https://doi.org/10.1016/j.jclepro.2 $\underline{017.12 .174}$

Xu XB, Yang GS, Tan Y. (2016). Factors influencing industrial carbon emissions and strategies for carbon mitigation in the Yangtze River Delta of China. Journal of Cleaner Production, 142:3607-3616. https://doi.org/10.1016/j.jclepro.2016.10.107

Yan YF, Yang LK. (2010). China's foreign trade and climate change: A case study o f $\mathrm{CO}_{2}$ emissions. Energy Policy, 38(1):350-356. https://doi.org/10.1016/j.enpol.2009. $\underline{09.025}$

Zang H, Wang M, Feng C. (2021). What determines the climate mitigation process of China's regional industrial sector? Environmental Science and Pollution Research, 28(8):9192-9203. https://doi.org/10.1007/s11356-020-11006-5

Zhang J, Jiang HQ, Liu GY. (2017). A study on the contribution of industrial restruct uring to reduction of carbon emissions in China during the five Five-Year Plan $p$ eriods. Journal of Cleaner Production, 176:629-635. https://doi.org/10.1016/j.jclepro. $\underline{2017.12 .133}$

Zhang L, Ma L. (2020). The relationship between industrial structure and carbon inten sity at different stages of economic development: an analysis based on a dynamic threshold panel model. Environmental Science and Pollution Research, 27(26):333 21-33338. https://doi.org/10.1007/s11356-020-09485-7 
Zhang SH, Worrell E, Crijns-Graus W. (2015). Evaluating co-benefits of energy efficie ncy and air pollution abatement in China's cement industry. Applied Energy, 147: 192-213. http://dx.doi.org/10.1016/j.apenergy.2015.02.081

Zhang ZQ, Qu JS, Zeng JJ. (2008). A quantitative comparison and analysis on the assessment indicators of greenhouse gases emission. Journal of Geographical Scien ces, 18(4):387-399. https://doi.org/10.1007/s11442-008-0387-8

Zhao X, Shang YP, Song ML. (2019). Industrial structure distortion and urban ecologi cal efficiency from the perspective of green entrepreneurial ecosystems. Socio-Eco nomic Planning Sciences, 72:Paper 100757. https://doi.org/10.1016/j.seps.2019.1007 $\underline{57}$ 
Figures

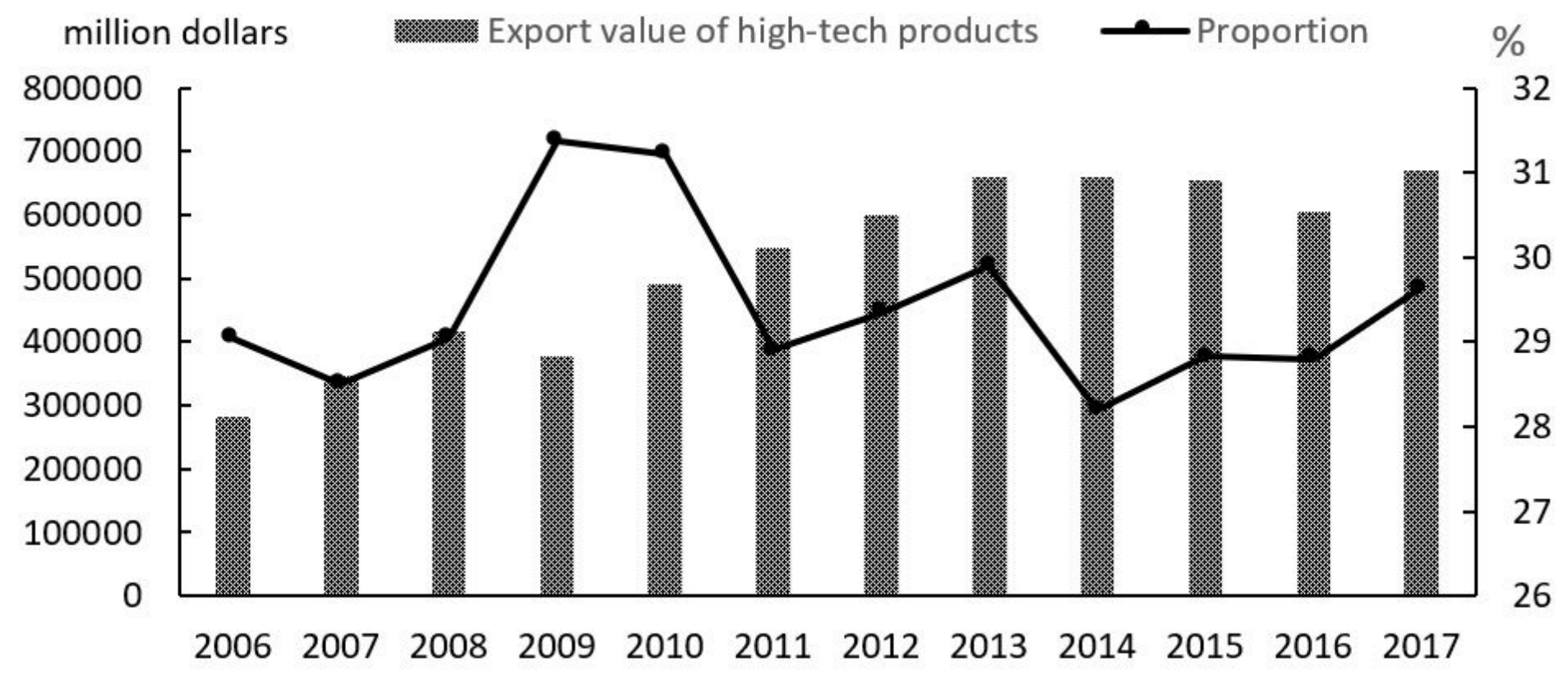

Figure 1

The export value of China's high-tech products and their proportion in total merchandise exports (20062017). Source: The annual data of China Statistical Yearbook of Science and Technology and China Statistical Yearbook.

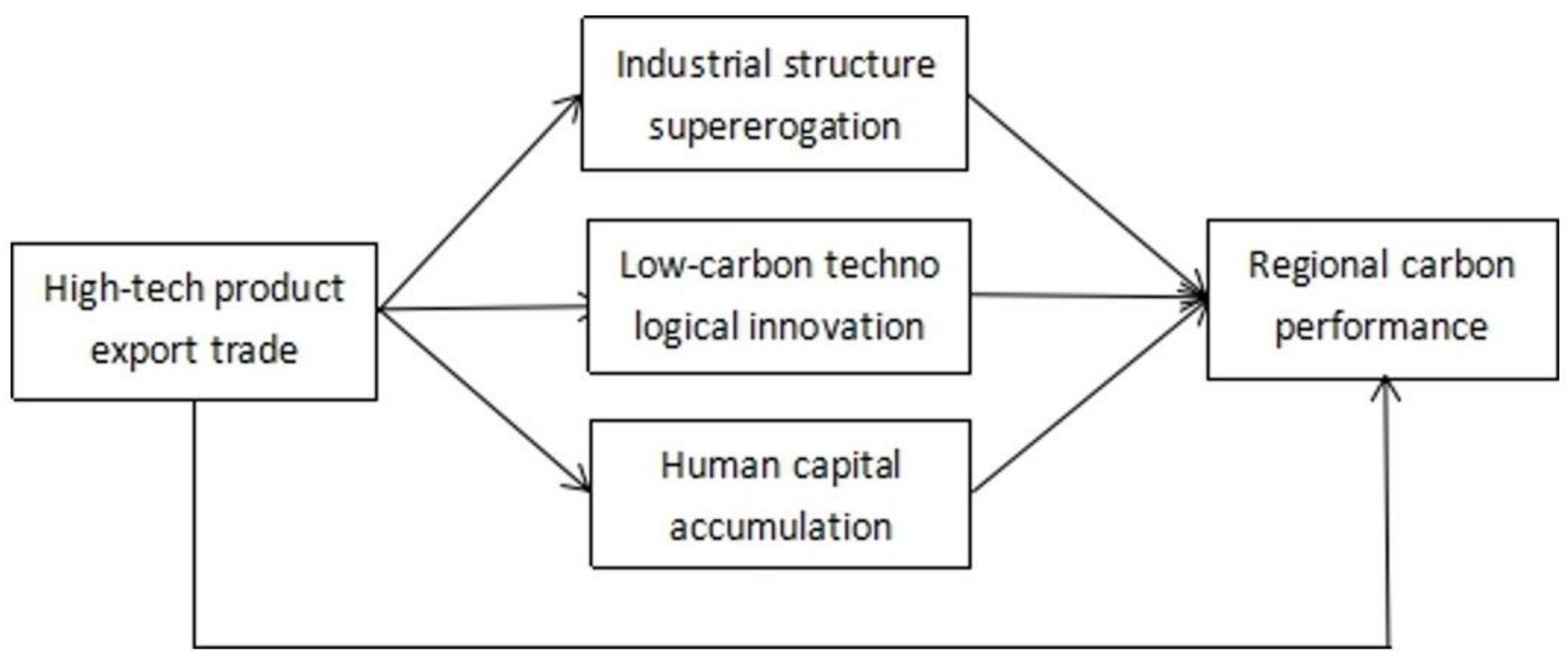

Figure 2

The impact path of high-tech product export trade on regional carbon performance 